\title{
NOSE TO TAIL: USING THE WHOLE EMPLOYMENT RELATIONSHIP TO LINK WORKER PARTICIPATION TO OPERATIONAL PERFORMANCE
}

\author{
Adam Seth Litwin \\ Cornell University
}

\begin{abstract}
Although many employers continue to adopt various forms of worker participation or employee involvement, expected positive gains often fail to materialize. One explanation for the weak or altogether missing performance effects is that researchers rely on frameworks that focus almost exclusively on contingencies related to the workers themselves or to the set of tasks subject to participatory processes. This study is premised on the notion that a broader examination of the employment relationship within which a worker participation program is embedded reveals a wider array of factors impinging upon its success. I integrate labor relations theory into existing insights from the strategic human resource management literature to advance an alternative framework that additionally accounts for structures and processes above the workplace level - namely, the (potentially implicit) contract linking employees to the organization and the business strategies enacted by the latter. The resulting propositions suggest that the performance-enhancing impact of worker participation hinges on the presence of participatory or participationsupporting structures at all three levels of the employment relationship. I conclude with implications for participation research.
\end{abstract}

Keywords: Worker participation; labor relations; employment relations; participative management; employee involvement

\section{INTRODUCTION}

Employers have long believed that engaging, involving, or otherwise empowering frontline employees enables organizations to leverage greater productivity from their workers. This belief, boosted in great part by the management delayering of the last three decades (Useem, 1992), explains the ubiquity of employee involvement or worker participation in its various shapes, whether they be explicit forms of direct communication between management and frontline workers or the implementation of team-based production or service models. Indeed, one can understand why with well over a half century's worth of research behind us, practitioners and scholars alike would assume the existence of incontrovertible evidence of the link between frontline worker participation and operational performance. After all, to those steeped in the study of work and employment, it certainly seems sensible that involving employees - granting them a modicum of discretion and inviting them to participate in decision-making once exclusively the province of their managers - should improve their individual performance and that a more productive workforce would make for a better-performing organization (Marchington \& Wilkinson, 2000). And, in fact, across sectors in the United States and abroad (Blasi \& Kruse, 2006; Kato \& Morishima, 2002; Poutsma, Ligthart, \& Veersma, 2006), organizations and their managers appear to have 
bought into this now-classic argument from the popular management press (e.g., McGregor, 1960; Ouchi, 1981).

All of this makes the absence of a clear-cut, empirical connection between worker participation, sometimes labeled employee involvement, and operational performance especially troublesome. ${ }^{1}$ Yet, such was the conclusion of Locke and Schweiger's (1979) extensive review of the literature, reinforced by subsequent reviews and meta-analyses suggesting that observed correlations were of little practical or economic significance, even in those cases in which they managed to achieve statistical significance (Miller \& Monge, 1986; Wagner, 1994; Wagner, Leana, Locke, \& Schweiger, 1997; Wall \& Wood, 2005). And, even these performance results often proved to be fleeting, either dwindling with time or as pilot programs were expanded to be plant- or organization-wide (Griffin, 1988; Lawler \& Mohrman, 1987).

As with any social science phenomenon under study, inconclusive results necessarily stem from weaknesses of the data, methods, research design, or most fundamentally, the theory or framework underpinning the hypothesized link between the independent and dependent variables. Indeed, recent studies aimed at addressing methodological shortcomings in earlier research, largely by giving up generalizability for increased internal validity and less unobserved heterogeneity, have more clearly revealed the participation-performance link (e.g., Jones, Kalmi, \& Kauhanen, 2010a; Litwin, 2011; Litwin \& Eaton, 2014). But, others have instead tried to bridge the gap by constructing contingency theories. Numerous personality traits have been theorized as moderators or mediators, including workers' perceived self-efficacy (Latham, Winters, \& Locke, 1994), need for independence (Abdel-Halim \& Rowland, 1976), and locus of control (Kren, 1992). Likewise, a number of scholars of strategic human resource management (HRM) have sought to advance theory by shifting attention from the people to the tasks themselves. For example, are the tasks subject to participatory processes "tactical," in the sense that they deal with precisely how work is to be done, or are they "strategic," in that they revolve more around whether or not the company should pursue production of a new product? Indeed, only limited support has been found for the use of this particular factor as a key moderator of the participation-performance link (Abdel-Halim, 1983; Sagie \& Koslowsky, 1994).

This study is not intended to be a comprehensive review of the massive literature on worker participation, however labeled. ${ }^{2}$ Rather, inspired in part by recent calls for renewing the intellectual conversation between labor relations and strategic HRM (e.g., Batt \& Banerjee, 2012; Kaufman, 2014), it instead responds to empirical ambiguity by appealing to the labor relations literature's three-tier approach to the employment relationship (Kochan, Katz, \& McKersie, 1986), folding it into strategic HRM research to better determine whether and when participation will drive performance. The emergent propositions initially draw from the literature's accumulated understanding of vertical and horizontal alignment or "fit" (Baird \& Meshoulam, 1988; Gerhart, 2007; Wright \& McMahan, 1992; Wright \& Snell, 1998). Thus, the theory allows contextual factors such as management's strategic responses to market exigencies to influence the instrumentality that frontline participatory structures ultimately have on organizational performance, thereby incorporating the vertical fit construct (Lengnick-Hall \& Lengnick-Hall, 1988; Youndt, Snell, Dean, \& Lepak, 1996). Moreover, even in situations in which business strategy, indeed, aligns with the use of participatory structures, one can ask, for example, whether or not workers are sufficiently motivated to leverage these structures toward organizational goals - horizontal fit (Appelbaum, Bailey, Berg, \& Kalleberg, 2000; MacDuffie, 1995). Therefore, the novelty of the approach offered here stems from its 
broader view of the employment relationship than has been typical of much of the received work on the participationperformance link. Unlike previous approaches, it does not appeal exclusively to contingencies related to the workers themselves or to the set of tasks subject to participative processes - what labor relations theorists would classify as "workplace-level" features or ascriptions of the employment relationship (Kochan et al., 1986). Rather, much like the culinary movement for "Nose to Tail Eating" that called for chefs to use "the whole beast" (Henderson, 2004), this framework draws on the entire employment relationship, leveraging the predictive value of strategies and structures that exert long-run influences on the nature of the relationship between a firm and its workers (Kochan, McKersie, \& Cappelli, 1984) - the "strategic" level or tier - and features of the implicit or explicit contract linking workers to employers - the "functional" tier of the employment relationship, over and above the attributes of individual workers, managers, and the tasks they regularly undertake.

The application of the three-tier framework to the participation problem thus informs the participation literature by shining light on underexamined, strategic- and functional-level determinants of the success of these programs. Furthermore, it addresses inconsistencies in received research linking worker participation to performance while offering a roadmap for future exploration of the application and effectiveness of frontline worker participation programs. In simplest terms, in situations in which participation cannot be linked to performance, could it be because the business strategy calls for participation, and participation is even supported by employment guarantees or performance-based compensation, but that true participatory structures and processes were never enacted on the frontlines? Likewise, one can imagine circumstances under which opportunities for participation have been created by line managers and are necessitated by business strategy, but are not reinforced by the employment contract. The theory developed here synthesizes core insights from strategic HRM and labor relations to illuminate instances like these and, more broadly, to inform those analyses seeking to predict whether and when participation will positively drive performance.

I first review existing theories and frameworks from strategic HRM tying participation to performance, noting the extent to which these limit themselves to constructs and contingencies at the workplace level. I then summarize research from strategic HRM and labor relations suggesting the additional explanatory power to be harnessed by a theory incorporating ascriptions of business strategy and of the contract, generally implicit, linking workers to organizations. I then draw on this work to propose a new, broader conceptualization of the labor relations context within which participatory structures and processes are embedded. The paper then explores the implications of the framework, first for managers and organizational leaders seeking to construct or repair participation programs for their own organizations. I conclude by considering the implications for understanding past research and for directing future studies.

\section{LIMITATIONS OF EXISTING THEORETICAL APPROACHES TO THE PARTICIPATION-PERFORMANCE LINK}

In their influential survey of empirical work on participation, Locke and Schweiger (1979) partitioned received theoretical mechanisms for the participation-performance link into two categories - cognitive and motivational. Under the cognitive heading, there were essentially two pathways by which participation could boost performance. First, involving frontline workers in decision-making would necessarily bring their information, knowledge, and creativity to bear 
on organizational or production-related issues, essentially channeling information from the shop floor or the frontlines up to middle managers or even to the boardroom. Cognitive benefits could also arise from the downward flow of information from managers. That is, workers could be more easily made aware of the rationale for a particular policy change or a production- or technology-related decision. Likewise, this cognitive pathway could increase goal clarity or provide workers "a fuller grasp of the methods to be used in accomplishing the work" (Locke \& Schweiger, 1979, p. 278). In either case, this would result in increased productivity, improved decision quality, reduced costs, or reduced conflict, sometimes through an increase in creativity or problem-solving. The chief causal mechanism on the motivational path is reduced resistance to change on the part of workers: where workers are consulted regarding organizational change, they are more likely to trust their organization and their managers and are also more likely to perceive themselves as in control (Coch \& French, 1948). They are more inclined to accept and commit themselves toward enacting these changes or decisions or to achieving the goals arising from them. This, they explained, stems from increased ego involvement or organizational identification or, perhaps, peer pressure or support from others in their workgroup. Again, this reduced resistance to (or increased acceptance of) decisions, it is theorized, leads to improved performance.

While management thinkers such as Pfeffer (1994), Becker, and Huselid (e.g., Becker \& Huselid, 2010; Huselid, 1995), for example, might make the case that certain HR (human resources) "best practices" would benefit nearly any organization that employs them, few if any scholars of worker participation are true "universalists" in the sense that Delery and Doty (1996) define the term with respect to strategic HRM. Rather, most studies, including Locke and Schweiger's (1979), instead focus on the contextual contingencies that mediate or moderate the causal connection between participation and performance. And, most of the contingencies examined in the literature revolve around individual differences between supervisors or between subordinates or perhaps even differences between managers and those they manage. For example, a number of organizational scholars have theorized and found support for the notion that the devolution of decision-making authority from managers to frontline workers only improves performance when frontline workers know something their managers do not (Kanter, 1983; Vroom \& Yetton, 1973). While these researchers were considering skills or know-how, the same arguments can be extended to service settings in which frontline workers interfacing with customers are the only people organization-wide with real-time information on their customers' specific needs (Frenkel, Korczynski, Shire, \& Tam, 1999), prompting the now common argument from organizational scholars that profit-maximization requires the organizational co-location of decisionmaking authority and information (e.g., Hitt \& Brynjolfsson, 1997). Others have examined personality traits (e.g., Abdel-Halim, 1983; McCurdy \& Eber, 1953; Vroom, 1960), including locus-of-control (Kren, 1992), selfefficacy (Bandura, 1986; Latham et al., 1994), and need for autonomy (Vroom, 1959), often mediated by job satisfaction, with varying degrees of success. For example, Abdel-Halim and Rowland (1976) find only weak support for hypotheses relying on the need for autonomy as a mediator of the participation-performance link. Likewise, Kren (1992) found that participation appeared to improve performance for those with an internal locus of control more so than for those with an external one.

Still other studies have asked questions not just of the individuals involved in participation programs, but of the span and characteristics of the matters subject to participative structures and processes. Vroom and Deci (1960) theorized that 
participation only boosts performance where work is nonroutine, though Abdel-Halim (1983) found little empirical support for this idea. Likewise, Wagner and Gooding's (1987) meta-analysis was unable to establish task-interdependence or task complexity as critical situational variables determining whether and when participation improves performance. An idea that has found strong empirical support is that workers' participation in decision-making around day-to-day, tactical matters - how best to do their work - is much more likely to improve performance than programs focused on more strategic sorts of decisions, such as whether or not to expand into a new line of business or to target a new customer segment (Sagie \& Koslowsky, 1994). Similarly the degree of influence afforded workers under a participation program, indeed, appears to influence the program's instrumentality over performance. That is, "informational” participation programs, in which workers are simply informed of managerial decisions and how they were arrived at, has less of a positive performance impact than do more substantive forms of participation in which workers are consulted prior to decision-making or in which workers are afforded actual rights of co-determination (Marchington \& Wilkinson, 2005; Riordan, Vandenberg, \& Richardson, 2005).

Rather than just focusing on the people or the tasks, a more-promising approach along these lines is to zoom in on the interface between specific employment practices and those affected by them. Wilkinson and Fay (2011) encourage us to ask

what specific practices actually mean to the actors, whether such schemes can improve organizational effectiveness and well-being, and the extent to which various practices [actually] allow workers to have a say in organizational decisions (66).

Indeed, a number of recent empirical studies have shown that the effectiveness of a practice or bundle of practices depends upon how they are interpreted and perceived by the workforce (e.g., Cox, Zagelmeyer, \& Marchington, 2006; Peters, Poutsma, Van der Heijden, Bakker, \& de Bruijn, 2014). Brown and Cregan (2008), for example, provide credible evidence that one should focus on just how much employees are embracing opportunities for participation. Nonetheless, just like those theories linking participation to performance by focusing on people or on tasks, theories examining meaning and perceptions are also focused squarely on the workplace level to the exclusion of structures and processes operating at higher levels of the employment relationship.

\section{FRONTLINE WORKER PARTICIPATION IN ITS BROADER CONTEXT}

A number of organizational researchers have argued that "context is king" with respect to the participationperformance link, acknowledging that theories predicated on personality measures fail to capture the complexity of the relationship between participation and performance (Neumann, 1987), that situational variables dwarf individual differences with respect to explanatory power (Steers, 1977), or that the role of organizational and technological ascriptions has been understudied (Connor, 1992; Litwin, 2011). In fact, received theory has not completely overlooked the role of organizational context, particularly attributions such as the size of the organization or of the problem-solving group (Locke \& Schweiger, 1979; Wagner \& Gooding, 1987), or what we might think of as industry-level descriptors (Connor, 1992; Wagner \& Gooding, 1987). Based on these and other findings, Glew, O'Leary-Kelly, Griffin, and Van Fleet 
(1995) proposed an especially rich sequential framework that called on both organizational and individual factors to moderate the relationship between intended and realized participative programs and between realized participative components and measureable performance outcomes. Likewise, they created a role for organizational and managerial motives for creation of the program, believing that these influence the intended shape of the participation program. Others have offered multidimensional frameworks that simultaneously consider the scope of the decisions subject to participative processes, the degree of influence afforded nonmanagerial workers, and sometimes even whether or not the program includes financial incentives (e.g., Frenkel et al., 1999; Marchington \& Suter, 2013).

Nonetheless, received theory has been constrained by its tight focus, usually on individuals or tasks, but occasionally inclusive of group-level or organization-level factors, which has led to piecemeal explanations for tying participation to performance. Instead of casting individuals, groups, or even organizations - all parties to the employment relationship — or tasks - themselves a product or perhaps a determinant of the employment relationship - as the relevant units-ofanalysis, the framework proposed here exploits the entire employment relationship as the unit-of-analysis. In the spirit of nose-to-tail eating, in which chefs make use not only of the fillet but of the often neglected bits of the animal (Henderson, 2004), this theory considers the "whole" of the employment relationship. In addition to examining the workplace manifestation of participative structures and processes, it considers two parts of the beast often left on the chef's table as he or she formulates their theory - the notions of business or management strategy and of the employment contract. In particular, it examines the interrelationships among factors at each of these levels and argues that the elusive, positive relationship between participation and performance will emerge once one considers all three levels of the employment relationship in concert.

\section{A Labor Relations Perspective on the Employment Relationship}

The labor relations literature offers a model of the employment relationship that serves as a useful starting point for illuminating the participation- performance link. The three-tier framework depicted in Fig. 1 was first suggested by Kochan et al. (1984) and elaborated in Kochan et al. (1986). The bottom tier of the framework, which the authors label the "workplace" level, refers to those activities through which workers and their supervisors relate to one another on a daily basis (Katz, Kochan, \& Colvin, 2008, p. 6). These include the formal participatory structures and processes through which participation is operationalized such as self-directed or offline teams (Bailey, Berg, \& Sandy, 2001). It also includes inter alia informal manifestations of participation, such as the extent to which managers or organizational norms allow frontline workers autonomy or opportunities to suggest material changes in how to meet customer needs (Litwin \& Eaton, 2014). To the extent one sees the workplace as the focal point for studies on worker-, group-, or task-level attributes, this level has been the implicit focus of most of the received work on the participation-performance link. And, while it may seem trivial, it is important to point out that without effective participatory structures at the workplace level, there is no reason to expect participation to improve performance at all (Litwin \& Eaton, 2014; Rubinstein, 2003).

Nonetheless, I argue there are important determinants of the participation-performance relationship that obtain above the workplace level. Aside from the establishment of formal or informal participatory structures, workers must be 
willing to put forth the discretionary effort required to effectively leverage participation (Appelbaum et al., 2000;

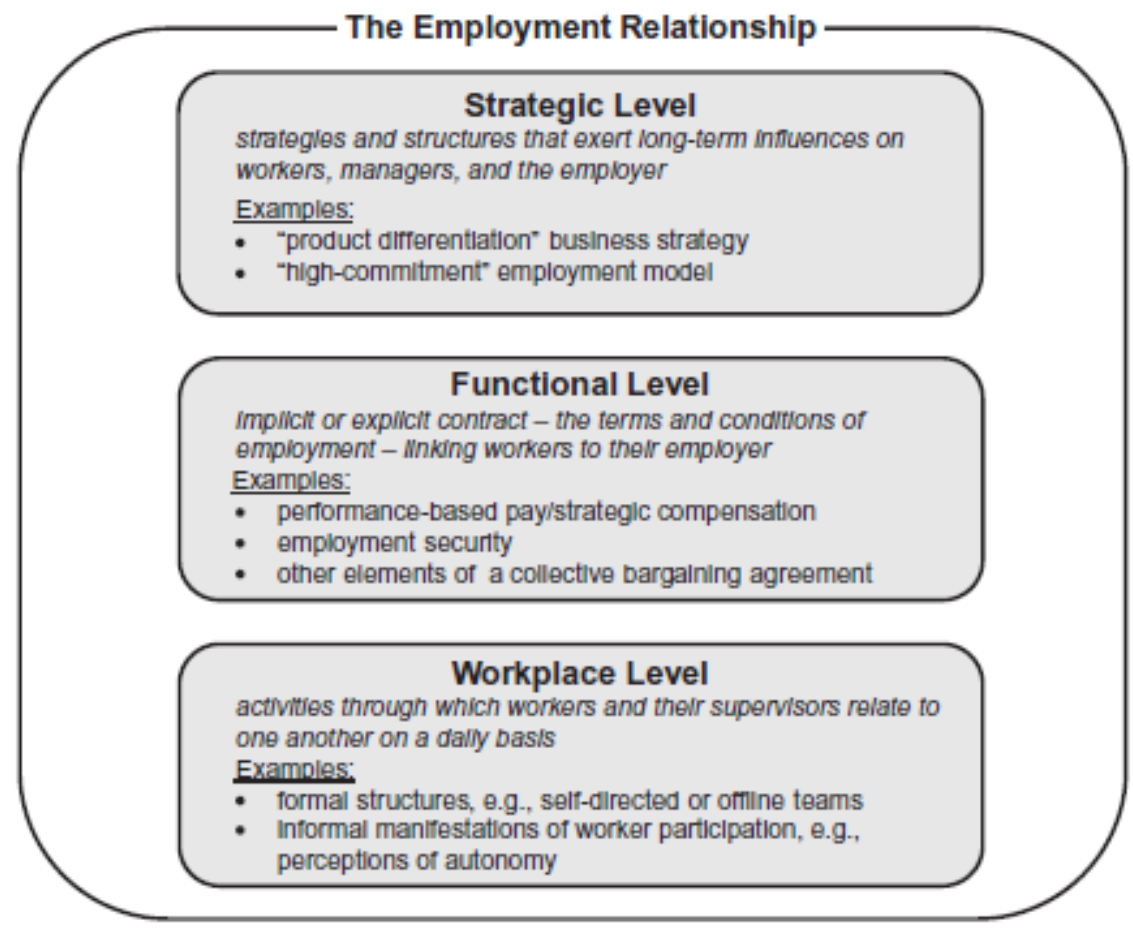

Fig. 1. The Three-Tier Model of the Employment Relationship. Source: Adapted from Kochan et al. (1986) and Katz et al. (2008).

Ichniowski \& Shaw, 2013; Jones, Kalmi, \& Kauhanen, 2010b). This requires the creation of participation-supporting structures on the middle level of the employment relationship, immediately above the workplace level. Now generally referred to as the "functional" level of the employment relationship, it encompasses the explicit or implicit contract linking workers to the organization. In particular, it describes the terms and conditions of employment. Often, the focus of research on this level is performance-based pay or any aspect of strategic compensation intended to boost performance. However, in the wake of a frontline worker participation initiative, one could likewise imagine "psychic" rewards such as employment or wage security being at least as important as explicit, positive performance incentives. And, indeed, many scholars have argued that such features of the employment contract are crucial in the wake of organizational changes that might otherwise come at the employee's own or his or her co-workers' expense (e.g., Becker \& Huselid, 1998; Pfeffer, 1994). Finally, located at the uppermost level of the three-tier framework is what its creators referred to as the "strategic" level: strategies and structures that exert long-run influences on the nature of the relationship between a firm and its workers (Kochan et al., 1984). These include issues related to business strategies as well as decisions regarding the employment or HR strategies necessitated (or allowed for) by these strategic choices. ${ }^{3}$

\section{HRM Theories of Horizontal and Vertical Alignment}

Horizontal and vertical alignment - sometimes labeled horizontal and vertical fit or internal and external fit - are two constructs that have featured prominently in strategic HRM theory. In broad terms, fit or alignment refers to the idea that 
the performance-enhancing effects of a particular HR practice are contingent on the presence of other HR practices or of contextual factors (Gerhart, 2007). Horizontal alignment focuses exclusively on HR practices, measuring the extent to which they are coordinated and congruent with one another, cohering to reinforce and, perhaps, complement one another (Baird \& Meshoulam, 1988; MacDuffie, 1995; Wright \& McMahan, 1992). Therefore, as Becker and Huselid (1998, p. 58) argue, horizontal alignment "improves as the various elements of an HRM system reinforce one another and send consistent signals regarding valued behaviors in the organization." They then provide an example of poor horizontal alignment: team-structured production or service processes alongside "incentive systems and career opportunities entirely linked to individual performance."

Vertical alignment, however, considers the link between employment practices and business strategy, positing that different clusters or bundles of employment practices - however well-aligned horizontally - may be differentially effective depending on the organization's business strategy (Gerhart, 2007). According to this theory, attempting to execute what Porter might label a "differentiation" strategy predicated on exceptional product or service quality in the wake of an employment model better- suited to a "cost leadership" or lowest-price strategy will result in suboptimal operational performance (Arthur, 1994; Youndt et al., 1996).

Despite early empirical substantiation for the performance benefits hypothesized of horizontal alignment (Huselid, 1995; Ichniowski, Shaw, \& Prennushi, 1997; MacDuffie, 1995), Gerhart's (2007) more recent review and critique of the strategic HRM literature has found the evidence wanting. He reaches the same conclusion with respect to studies of vertical fit, determining that the evidence is "mixed at best" (329). Nonetheless, these constructs, once grafted on the three-tier model of the employment relationship can be employed to shed light on the participation-performance link. Even if one is willing to accept that for frontline worker participation, "the rubber really does meet the road" at the workplace level - explaining why so many studies to date have focused on it - there remains a critical role in theory and practice for structures and processes at the strategic and functional levels of the employment relationship.

Fig. 2 simply recasts the previous figure in an effort to clarify the roles that vertical and horizontal alignment play in the analysis of an employment relationship. The bidirectional arrow connecting the workplace and functional levels of the employment relationship is not establishing the existence of a causal or even necessarily correlative relationship. Rather, it represents horizontal alignment - that is, the extent to which the functioning of formal or informal participative structures and processes at the workplace level is reinforced (or at least not undermined) by the terms of the employment contract. The other two bidirectional arrows illustrate the role that vertical alignment plays in a theory linking participation to performance. That connecting the strategic and workplace levels assesses the extent to which management's chosen business strategy comports with workplace-level participatory structures. And, the arrow connecting the strategic and functional levels captures the extent to which business strategy is consistent with the terms and conditions of employment. Therefore, Fig. 2 sows the seeds for a model in which operational performance 


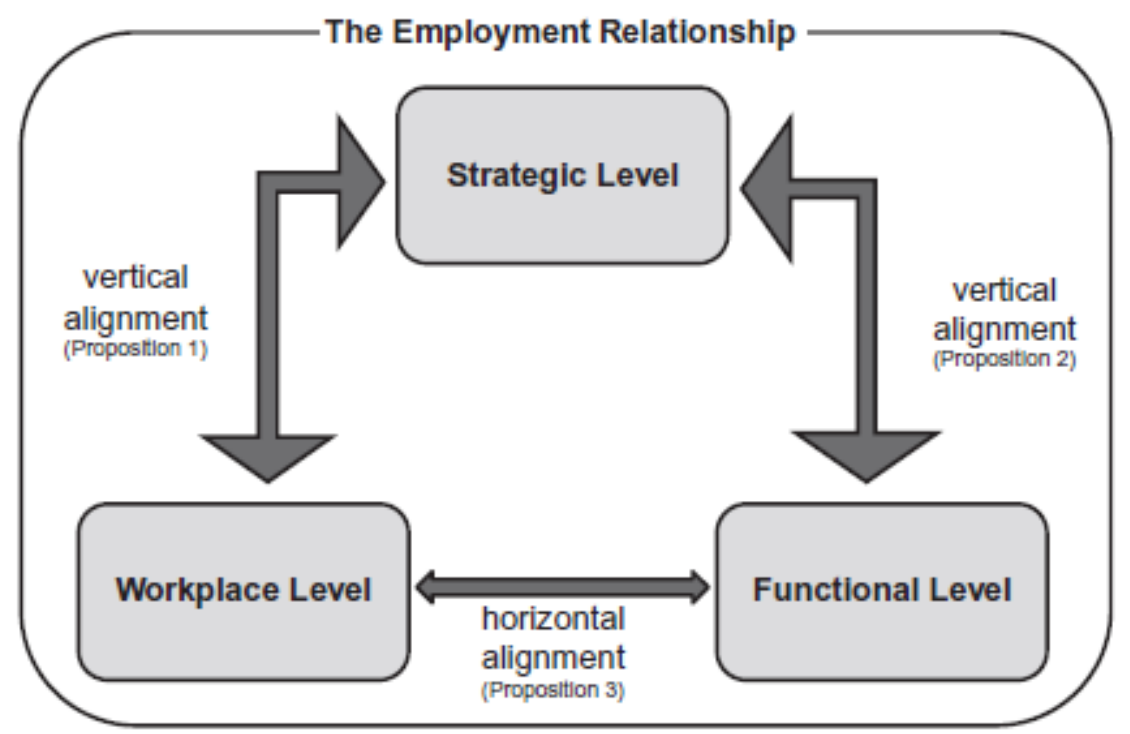

Fig. 2. The Three-Tier Model of the Employment Relationship Rearranged to Showcase Horizontal and Vertical Alignment.

ultimately hinges on the presence of participatory or participation-reinforcing structures at each of the three levels of the employment relationship and in which these structures reinforce one another across levels. The model is multiplicative in the sense that each level provides key structural support for the other two, implying that the presence of participatory structures on just one or even two levels of the employment relationship will be ineffective and probably short-lived in generating operational improvements.

\section{Propositions}

As alluded to above, the formal propositions are premised on the notion that the real value-enhancing properties of participation do, indeed, inhere in workplace-level structures and processes. Indeed, this is likely why studies have focused on ascriptions of workers or tasks or on the incidence of team-based work systems, quality circles, and the like. This yields an important implication for theory-building by presuming that irrespective of the care organizations put into constructing strategic- and functional-level participation-supporting structures, the absence of workplace-level structures ensures that these will not improve performance. In fact, one could make the case that without workplace-level manifestations of participation, there really are no structures to which one can link performance outcomes. Consequently, the propositions describe the relationship between presumed workplace-level participatory structures and those participation-supporting structures that potentially exist at the two higher-level tiers of the employment relationship.

The first proposition brings the vertical integration construct to bear on the three-tier model. It does so by examining participation-enhancing structures at the strategic level to determine whether managerial and organizational goals are even served by participation, the idea being that workplace-level participatory structures will do little for performance if instituted in the absence of a strategy that calls for them. Typically, a discussion of vertical fit takes place in the context of a "horse race" between those strategic HRM theorists espousing a universalistic perspective and those espousing a 
contingency one, the latter arguing that the performance impact of innovative employment practices is conditional on the firm's choice of business strategy (Delery \& Doty, 1996; Youndt et al., 1996). In the present case, the argument is simply that in order to be effective, workplace-level participatory structures must "coincide and be reinforced by ... organizational policies and practices" (Leana \& Florkowski, 1992, p. 259). So, for example, to the extent that participatory structures demanding new analytic or quantitative skills are to be successful, they will likely require large-scale investments in training. Likewise the effective devolution of decision-making to the frontlines is likely to necessitate outlays for new technologies that facilitate the exchange of real-time data and information (Litwin, 2013). Unit-level managers are unlikely to have the resources for or perhaps even the discretion to make such investments. And, where they do have the resources and the autonomy, this is the result of a strategic choice on the part of organizational leaders to promote frontline worker participation through flexibility and resiliency, and it exemplifies the embeddedness of the participation strategy across the firm's many layers (Cox et al., 2006; Lengnick-Hall \& Lengnick-Hall, 1988). Of course, this sort of alignment or realignment is unlikely to happen - either on its own or through deliberate action on the part of first-level managers unless the entire organization is oriented around a particular business strategy that necessitates, among other things, participatory structures and processes at the workplace level. Consequently, one should expect workplace-level participatory structures to be more effective at boosting performance in cases in which the business strategy actually calls for these structures.

Proposition 1. An organization achieves greater performance benefits from frontline worker participation when structures and processes at the strategic level are vertically aligned with those at the workplace level.

Fig. 2 implies that in the context of the three-tier model, there is actually a second pathway representative of vertical alignment - that linking the strategic level not to the workplace level, which was accomplished in Proposition 1, but rather to the functional level. Recall that the functional level of the employment relationship is centered on the generally implicit contract linking employees to their employers. As such, it encompasses all issues related to the terms and conditions of employment. The agreement could be an explicit one between workers and their managers made at the time of hire or, in a collective bargaining context, a formal contract renegotiated at regular intervals. Even under these decreasingly common employment arrangements, limited foresight, imprecise language, and the simple cost of having to consider every possible eventuality - collectively, bounded rationality - nearly ensure that every employment contract is incomplete (Milgrom \& Roberts, 1992; Simon, 1951). In reality, many of the terms and conditions governing most employment contracts are just as likely to emerge over time through the development of norms and customs (Osterman \& Burton, 2005).

Two critical participation-supporting features on this middle level are incentives and rewards, and a key issue that arises with respect to worker participation is whether or not the emergent terms of the contract actually reinforce or instead undermine the underlying business strategy. This is not to imply that there is a single, ideal employment contract in the context of a business strategy that calls for participation. Rather, the employment contract must be congruent vertically aligned - with the details of the particular strategy chosen by the organization. For example, a product differentiation, "high-quality" business strategy would be poorly served by a piece-rate pay program that rewards 
throughput without regard to product quality. However, the same incentive system could be ideal for firms competing on the basis of cost (Arthur, 1992).

To the extent that participatory structures are intended to yield new production or service efficiencies, an often overlooked but critically important reward is employment security - some sort of credible pledge from the employer that the efficiency improvements intended of the participation program will not result in job loss (Appelbaum et al., 2000; Pfeffer, 1994). Absent this signal of reciprocal commitment (Robinson, Kraatz, \& Rousseau, 1994), employers and employees will hold competing interests that keep them focused on zero-sum distributional issues rather than on a common, integrated business strategy aimed at value creation. In the net, in order for participation to effectively improve performance, it must be the case that participation-supporting structures at the strategic level are backed-up by the terms and conditions of employment as reflected on the functional level.

Proposition 2. An organization achieves greater performance benefits from frontline worker participation when structures and processes at the strategic level are vertically aligned with those at the functional level.

In the language of the three-tier model, horizontal fit describes the extent to which the functional and workplace levels are aligned with one another. In other words, do the terms and conditions of the employment contract promote the effective functioning of participatory structures and processes on the workplace level? From the abstract perspective of an HR theorist, this might be construed as the extent to which those workers granted decision-making rights have also been recast as owners of the firm or at least residual claimants on its revenues (Makadok \& Coff, 2009). From the more concrete perspective of strategic HRM, horizontal alignment boils down to the extent to which the structure of work comports with the incentives provided by the contract. The example of horizontal misalignment raised above revolved around the provision of individual-based incentive payments, generally incompatible with team-based work systems or the undertaking of any set of tasks that are highly interdependent and require cooperation between coworkers (Wageman, 1995). Related to the issue of incentives, it is also through horizontal alignment that those workers possessing unique knowledge, information, or data not available to others in the firm get incentivized to leverage that information toward the best interests of their employer (MacDuffie, 1995).

Horizontal alignment can also be used to solve an intra-organizational "public goods" problem that would otherwise lead to an "undersupply" of input from workers - irrespective of how carefully participatory structures have been crafted in the workplace. That is, individual employees are likely to perceive reputational costs associated with "speaking up," particularly to the extent that the information they provide implicates a particular manager or threatens the reputation of someone above them in the organizational hierarchy. As a result, despite their otherwise active engagement in workplace-level participatory structures and the fact that the marginal benefit to the organization far exceeds the marginal social cost of providing the information, the worker will rationally decide that the personal cost to himself or herself dwarfs their share of the anticipated benefit (Marsden \& Canibaho, 2010). Under this situation, horizontal alignment - just as in the case of vertical alignment - would necessitate some form of employment protection or due process to accompany programs aimed at eliciting valuable information not broadly available across the organization. And, in general, the more 
aligned the employment contract is with the nature of participatory structures and process in the workplace, the more likely an organization is to glean performance benefits from frontline worker participation.

Proposition 3. An organization achieves greater performance benefits from frontline worker participation when structures and processes at the functional level are horizontally aligned with those at the workplace level.

In sum, the three propositions scaffold a framework in which participatory structures and processes at each of the three levels of the employment relationship must be present to support one another, without which the link between workplace-level participatory structures and processes and operational performance will be diminished if not altogether missing. Stated positively, the performance-enhancing potential of participation for organizations is increasing in (1) the extent to which the business strategy calls for the particular form of participation employed (Proposition 1) and the degree to which (2) the employment contract correctly reflects these strategic goals (Proposition 2), and (3) promotes the effective functioning of workplace-level participatory structures and processes (Proposition 3).

\section{DISCUSSION}

In an effort to explain whether and when workplace-level structures falling under the rubric of frontline worker participation will actually benefit operational performance, I have unearthed a framework from labor relations that had previously been used primarily in a very different context. In broad terms, I have evoked the nose-to-tail metaphor to make the case that while previous attempts to explain the participation-performance link make excellent use of "prime," workplace-level cuts from the employment relationship, the literature has collectively squandered perfectly useful strategic- and functional-level parts of the animal. In particular, I proposed that irrespective of the incidence, form, and quality of participative structures in the workplace, their instrumentality over performance hinges on two additional groupings of employment relationship features - the alignment of which has long been a subject for strategic HRM research. First, the employer's business strategy must be one whose success depends upon the performance-enhancing capabilities of workplace-level participation. Likewise, business strategy must be in tune with the nature of the employment contract - the terms and conditions of employment - linking the organization to its workers. Together, these propositions constitute vertical alignment. Second, the employment contract, aside from being aligned with business strategy, must be one that promotes frontline worker participation in the workplace, usually by guaranteeing workers some share of the benefits - pecuniary or otherwise. This closely resembles what strategic HRM scholars refer to as horizontal alignment or fit.

\section{Theoretical Contributions}

These propositions yield significant implications for theory and research not only on the phenomenon of employee involvement, but more broadly for two domains that have often approached workplace phenomena from disparate directions - strategic HRM and labor relations.

\section{Frontline Worker Participation}

The conceptual model, while assuredly an abstraction, offers researchers a clear understanding of why the 
participation-performance link may be elusive in a given setting. It does so, in part, by responding to an abiding call for more deliberation around the organizational context within which a given participation program is deployed (Neumann, 1987; Steers, 1977), in this case, yielding a more structured role in theory-building for features of the employment relationship. Moreover, it does so along the lines called for by Glew et al. (1995) who suggested that researchers consider the managerial or organizational motives for instituting a participation program. In examining vertical alignment, for example, we are considering the strategic motives for the deployment of participation at the workplace level. And, in the absence of a strategic motive or in the presence of a strategy that does not call for participation, one should not expect a participation- induced performance improvement. More broadly, the theory propounds that aside from there being participatory structures and processes in place at the workplace level, there must be participation-reinforcing structures and processes at both the functional and strategic levels. As I will explain below, this perspective differs from the usual approach to innovative employment practices that essentially argues that any single HR practice, irrespective of the employment relationship level to which it pertains, will complement (or perhaps cannibalize) the performance impact of each of the rest of the practices implemented (Becker \& Huselid, 1998). Based on the nose-to-tail framework, for example, no inventory of workplace-level participatory practices will improve performance in the absence of a strategy whose success hinges on participation.

To illustrate further, the framework helps us understand why researchers may fail to uncover participation's anticipated performance improvements even when workplace-level participatory structures are the product of deliberative and earnest frontline managers. First, it could be the program under study was installed in some formal or informal manner at the workplace level, but that frontline workers were not adequately incentivized or protected at the functional level. Thus, workers may not have actively and fully engaged in the program, implying horizontal misalignment as the cause of lackluster or dampened performance improvement. Second, even if participatory structures and processes were reinforced by well-aligned forms of incentive compensation and perhaps even pledges of employment or wage security, absent a business strategy that depends upon worker participation, one should not expect a mechanical link between high- functioning participative structures at the workplace level and measures of operational performance. This disconnect can come about in at least two ways, both of which result from vertical misalignment. First, without being scaffolded around an overarching business strategy, workplace-level participatory structures are unlikely to be supported by investments in training, product or plant retooling, or changes in work structures required to glean maximum performance benefits from frontline worker participation. Second, even if somehow the program can operate effectively without organization-wide support, there will be no direct connection between high-performing teams, quality circles, or the like - perhaps focused on a quality-related outcome - and operational performance if business strategy is predicated around outcomes other than (and perhaps orthogonal to) quality. The framework also points to what some might view as the more common counterpoint to these examples: that is, organizational leaders, indeed, make a clear strategic choice to embrace a business strategy that relies on frontline participation, but the strategy never gets embedded or negotiated into the employment contract, never makes its way down to the frontlines, or, perhaps, yields workplace-level participatory structures and processes of different or weaker form than those intended (Litwin \& Eaton, 2014). As I will 
explain below, against the backdrop of the nose-to-tail framework, this same phenomenon yields implications for managers as well as for researchers.

The same two explanations - vertical and horizontal misalignment - can be brought to bear on received empirical analyses of the participation - performance link, including many of those considered in the systematic reviews discussed previously (e.g., Locke \& Schweiger, 1979; Miller \& Monge, 1986; Wagner, 1994). In light of the theory presented here, one could revisit many of the empirical studies summarized or meta-analyzed in those pieces, testing the hypothesis that each of these studies is essentially a particular case within the nose-to-tail framework. That is, in those studies that do not reveal a clear participation-performance link, was there, in fact, a dearth of participation-reinforcing structures at the strategic and/or functional levels? Likewise, most of those empirical studies in which the participation-performance link obtains were multimethod, single-industry, or single-organization investigations in which strategic- and functional-level variables could at least be held constant (e.g., Jones et al., 2010a; Litwin, 2011; Litwin \& Eaton, 2014). Consequently, these, too, could well be special cases of the nose-the-tail framework in which reinforcing structures at higher levels are, indeed, vertically and horizontally aligned. Additional support for the framework comes from those studies that while not propounding a particular theory or framework determined that participation schemes have more instrumentality over performance when workplace- level programs are "real" or "substantive" or offer a genuine degree of influence as opposed to mere information-sharing (Levine \& Tyson, 1990; Marchington \& Wilkinson, 2005). That is, programs that are successful at the workplace level are reinforced by the employment contract and operate in service to business strategy.

\section{Strategic Human Resource Management}

The nose-to-tail framework also speaks to strategic HRM. It does so by critiquing the sometimes putative notion that "more is better than less" with respect to innovative employment practices such as those associated with or necessary to support frontline worker participation. One critical distinction between the HRM literature that emerged in the 1960s and 1970s and the strategic HRM literature that first surfaced in the late 1980s is the belief inherent in the latter that coherent, mutually-reinforcing bundles, clusters, or systems of employment practices rather than individual employment practices, no matter how innovative, are what drive performance improvements (e.g., Arthur, 1994; Becker \& Huselid, 1998; Huselid, 1995; Ichniowski et al., 1997). While theories of complementarity have evoked discussion over whether one should analyze employment practice synergies additively or multiplicatively (e.g., Becker \& Gerhart, 1996; Cappelli \& Neumark, 2001), the theory developed in this paper implies that simply counting practices - whether they are ultimately summed or multiplied - is a flawed approach. Rather, what matters for linking employment practices to performance is that $\mathrm{HR}$ systems include mutually reinforcing practices from each of the three tiers of the employment relationship.

Given the "general consensus that [alignment] ought to play a central role in [strategic HR theory]" (Becker \& Huselid, 2010, p. 354), it is somewhat alarming that many of the most-cited empirical papers in strategic HRM find scant evidence for fit hypotheses, vertical alignment in particular (Becker \& Huselid, 1998; Delery \& Doty, 1996; Huselid, 1995). Confidence is only further undermined by reanalyzes of those studies that originally corroborated theories of vertical and horizontal fit. As alluded to above, Gerhart (2007), for example, found that claims of a link between horizontal alignment 
and performance offered by Appelbaum et al. (2000), Ichniowski et al. (1997), and Laursen and Foss (2003) were weakened when subjected to his additional methodological scrutiny. Nonetheless, the theoretical advance made in this paper could help "save the null" if it prompts researchers to revisit earlier studies with a new approach to how one analyzes the employment relationship. That is, one should begin by identifying and accounting for workplace-level participatory structures and processes. When they are absent, one should not expect innovative incentives on the functional level or any particular business strategy on the strategic level - or even the two of them in tandem - to be positively associated with operational performance. Where researchers positively determine the presence of workplace-level participatory structures, the framework here suggests that one first search for a business strategy that requires workforce participation and then for an employment contract that supports the establishment and continued effectiveness of these workplacelevel structures. The nose- to-tail framework implies that the incidence and alignment of participatory or participationsupporting structures across all three levels of the employment relationship will, indeed, serve as a reliable driver of operational performance.

\section{Labor Relations}

The nose-to-tail framework also extends and informs the literature from which the three-tier model was drawn, labor relations. The original impetus for Kochan et al. (1986) theoretical framework was an attempt to explain what appeared to be structural changes in US labor-management relations, partially the result of an exogenous intensification in product market competition and the weakening of institutions that once buttressed collective bargaining (Kochan et al., 1984). ${ }^{4}$ As a result, by bringing the three-tier model to bear on frontline worker participation, an organizational and work-related phenomenon distinct from collective bargaining, the nose-to- tail framework typifies the ways in which theory developed in a relatively highly unionized context can be extended to understand the impact of a broader set of institutional changes taking place within the confines of the employment relationship. Therefore, this study constitutes a theoretical contribution to the largely empirically oriented set of papers (e.g., Litwin, 2013) that already respond to the call that theorists of HRM revisit seminal work in post-Marxist, pluralist, labor relations (Kaufman, 2014).

At the same time, the nose-to-tail framework also informs what some may see as a counterintuitive empirical result in labor relations - the apparent synergy between worker participation programs and collective bargaining with respect to performance (e.g., Bryson, Forth, \& Kirby, 2005; Kochan, Eaton, McKersie, \& Adler, 2009; Levine \& Tyson, 1990; Litwin \& Eaton, 2014). Indeed, this phenomenon belies a well-reasoned explanation that since our present-day collective bargaining structures grew out of "job control" unionism which itself developed around scientific management - in which decision-making is centralized and planning is entirely separated from execution - that collective bargaining should undermine attempts to broaden the role of frontline workers or to give workers more opportunities to shape production or service delivery. Nonetheless, the present framework explains this empirical result by suggesting that collective bargaining provides the necessary structure within which participation programs can thrive. This comes about as a result of the relatively explicit nature of the employment contract and the more centralized approach to managing people that one is likely to find in a unionized context. Managers and organizational leaders are keenly aware of the ways in which their employment contract enables or hinders the operationalization of their key strategic decisions, facilitating vertical 
alignment as embodied in Proposition 2. Likewise, unionized workers are more likely to have well- developed channels for reporting those situations in which middle and lower-level managers have constrained the operations of workplace-level participatory structures to be narrower than that intended by those at the strategic level (Litwin \& Eaton, 2014) indicative of vertical alignment as embodied in Proposition 1.

\section{Practical Implications}

The framework advanced here also offers valuable lessons for organizational leaders looking to design or reform a participation program as well as for those managers beneath them in the organizational hierarchy seeking to explain lackluster performance results in the wake of a participation initiative. Organizational leaders must realize that workplacelevel participatory practices mandated from the boardroom are unlikely to engender performance improvements unless they are the product of a business strategy that depends on them. Eaton, Konitsney, Litwin, and Vanderhorst (2011) refer to a specific illustration of the importance of vertical alignment of this nature in a healthcare organization. When a team of registered nurses (RNs) wanted to encourage select patients to take a series of steps to reduce reliance on a relatively costly medication, they required the help of those in a completely separate part of the organization, the information technology (IT) group, to gather data from the patient registry. In the past, the IT group would not have prioritized the request from the RNs, but participation-supporting structures at the strategic level ensured that the IT department understood the role that it must play in supporting the work of this particular team and of other frontline teams in the organization working toward similarly IT-dependent performance goals. Therefore, this emerges as a real-life exemplar of vertical alignment as called for in Proposition 1.

Aside from the need for participation-supporting structures to be embedded in this way across the organization (Cox et al., 2006), there is a second practical reason why vertical alignment matters for the success of frontline worker participation. When participation is predicated on deep-seated business strategy, organizational leaders are more likely to take deliberate steps to eviscerate the aspects of the organizational power structure that would otherwise stand in the way of the creation of workplace-level participatory structures. Given wide latitude to design and administer participative structures and processes, those managers closer to the frontlines are unlikely to cede authority and control to those in their charge (Klein, 2003; Lavelle, Gunnigle, \& McDonnell, 2010). Indeed, why would they in an environment in which managers are "on the hook" for their department's performance? What results is a form of participation that is more centered on consultation with rather than co-determination by workers - that is, participatory structures with less power and less influence over performance than that which had been intended by organizational leaders (Khilji \& Wang, 2006). Proposition 2 of the nose-to-tail model implies that improved vertical alignment - this time, between the strategic and functional levels, is called for. In this case, one can imagine that recasting the employment contract for managers shifting the focus from objective performance outcomes to measures of the extent to which they have actually devolved decision-making authority to frontline workers - could ultimately further the operational performance goals at the core of the participation program.

Finally, Proposition 3 - which employs the construct of horizontal alignment to bridge functional- and workplace-level 
participatory structures - offers perhaps the most palatable implications of the theory, essentially just a specific case of not "rewarding A while hoping for B" (Kerr, 1975). There are a number of all-too-common ways in which the terms and conditions of employment undercut rather than bolster the productivity goals of a frontline worker participation program. For example, contingent pay may be pegged to individual as opposed to group performance, decaying at the cooperation and coordination required for the completion of highly interdependent tasks. Similarly, for the vast majority of employees working under implicit (or at least nonexplicit) employment contracts, managers or organizational leaders often neglect to make clear to workers that performance gains arising from improved performance will not lead to job loss or wage decay. In the absence of such employment and wage guarantees, workplace-level participatory structures so far out of horizontal alignment, no matter how painstakingly designed and instituted, cannot be expected to deliver improved performance.

\section{FUTURE DIRECTIONS}

Aside from validating the framework empirically, researchers can draw from and perhaps further extend it to shed more light on the ways that worker participation generates - and sometimes fails to generate - value for organizations and their stakeholders. First, in its present form, as expressed in Fig. 2, the framework focuses almost exclusively on goings on inside the employment relationship. Therefore, while it acknowledges the existence of external forces impinging upon employment relationships, particularly with respect to managerial choices made at the strategic level, it falls prey to accusations of managerialism (Kochan, 1999) by failing to consider these forces in any detail. Consequently, a logical extension to this framework would account for economic, technological, political, or social forces, among others, that either act upon labor relations features at any of the individual levels or that shape the interrelationships between levels. Indeed, many such extensions have long been considered and incorporated by those seeking to use the original, threetier model for its original purpose, the study of collective bargaining processes and outcomes (Budd, 2004). As noted above, the impetus for Kochan et al.'s (1986) original formulation of the three-tier model was to explain how an employer's behavioral reaction to an intensification in product market competition (Kochan et al., 1984) translates into changes in their orientation toward managing people, and others have adopted this approach to model managerial reactions to technological change (Litwin, 2013). Nonetheless, the explanatory power and usefulness of the framework advanced here for illuminating the participation-performance link could no doubt be strengthened by a rigorous reconsideration of those external features whose dynamic nature shapes and often reshapes employment relationships.

Second, the above discussion of practical implications reveals that the nose-to-tail framework does not unpack the potential discrepancies in interests and incentives that no doubt exist between employers in the shape of owners and employers in the shape of managers. It may be sensible to assume that owners' main financial interests lie in profitability, but managers, with varying degrees of ownership, confront a broader range of concerns, financial and otherwise (Jensen \& Meckling, 1976). The subgoal optimizing that result from these incongruities (March \& Simon, 1958) could well yield workplace-level participatory structures that differ in form, scope, or degree of influence from those required of business strategy and directed by organizational leaders. That is, as alluded to above, if managers are given leeway in shaping participatory structures, they may choose to define the redistribution of power in very narrow terms, limiting the extent 
to which they must cede some of their decision-making authority and control over resources (Khilji \& Wang, 2006; Lavelle et al., 2010; Litwin \& Eaton, 2014). Empirical examination can reveal the extent to which this phenomenon obtains and can illuminate the ways that organizations and their managers can mitigate this counter-productive behavior. In the meantime an institutional or inertial theory (Hannan \& Freeman, 1977) serves a priori as a reasonable explanation for the persistence of vertical or horizontal misalignment under these circumstances. In this case, institutional inertia would arise from the often intractable forces that limit the employment relationship's ability to reshape itself around a newly unveiled business strategy, even if the changes appear to be in the best interest of the organization, its employees, and the employment relationship more broadly (Hannan \& Freeman, 1984). While management scholars originally applied inertial theory to explain organizational failure (e.g., Carroll, 1987; Meyer \& Rowan, 1977; Singh, House, \& Tucker, 1986), HR scholars have employed it to explain the uneven adoption of performance-enhancing approaches to managing people (Lepak \& Snell, 2002) or of productivity-enhancing changes to the design of work (Dean \& Snell, 1991). It has also been called on to explain the persistence of suboptimal worker incentives in the wake of technological change (Litwin, 2013; Snell \& Dean, 1994).

This sociological approach stands in stark contrast to the standard principal-agent framework that management researchers have traditionally used to explain suboptimal behavior on the part of managers. That is, those managers "behaving badly" need to have their interests aligned with those of the firm, effectively imparting managers with an ownership stake. Irrespective of whether researchers approach the weak participation- performance connection from an institutional or an agency perspective, the framework advanced here suggests they cast the phenomenon as a case of misalignment. That is, the disconnect could be the result of vertical misalignment in the sense that business strategy is not being served by emergent participatory structures at the workplace level. Alternatively, this phenomenon may be the product of horizontal misalignment if instead the employment contract linking managers to their employer itself needs to be revised such that managers are rewarded for the success of the participatory structures in their charge rather than for simply establishing and administering participatory structures in their departments or units. The upshot is that sorting out the specific source of misalignment limiting the instrumentality of participation on performance could yield a more nuanced course of action for those managers or researchers seeking to diagnose and treat this issue. This implies that that deeper thinking about the specific causes of vertical or horizontal misalignment within this framework could make it even more useful for future theory-building and, ultimately, practical application.

Aside from a more refined approach to the role of managers, the theory could likewise be augmented by incorporating recent structural changes in the way that workers relate to firms (Kalleberg et al., 1997). One can imagine that the supplanting of conventional employment relationships with contracting and outsourcing (Bidwell \& Fernandez-Mateo, 2008) and the related proliferation of various sorts of labor market intermediaries (Bonet, Cappelli, \& Hamori, 2013) could complicate the relationships expressed in Fig 2. For instance, frontline worker participation could be especially difficult to install where workers are more beholden to a temporary help firm or a professional employer organization rather than to their de facto employer, that is, the client firm with whom their agency contracted for their services (Kalleberg, Reskin, \& Hudson, 2000). Furthermore, these workers would be less likely to see themselves as vested in the long-term success of 
their de facto employer. Consequently, they would be less likely to invest in their employer by climbing the participation learning curve or by accepting compensation packages that allow a large share of rewards to be contingent on performance and likely deferred. Likewise, their de facto employer would be disinclined ex ante toward making the large upfront investments often required of participation programs (Levine \& Tyson, 1990; Marsden \& Canibaho, 2010). Managers may even feel unable to institute a participation program for these workers (Marchington, Grimshaw, Rubery, \& Willmott, 2005), owing to the fact that their own organization is not the actual employer, either legally or in terms of administrative control (Kalleberg et al., 2000; Pfeffer \& Baron, 1988). Each of these implies a different impediment to vertical or horizontal alignment, implying that nonstandard or triadic employment relationships, aside from attenuating the incidence of participation, could further weaken the link between participation and performance.

However, contracted employees are actually more likely to work under an explicit as opposed to implicit employment contract, albeit one that was actually negotiated not between themselves and the firm, but rather between the firm and the employment agency. This could actually allow for more frequent renegotiation and readjustment of the terms and conditions of employment as well as for more concrete enunciation of the behaviors required of workers under the participation program and the incentives that they are being provided in exchange for these efforts. This frequent, horizontal realignment would be expected to strengthen the participation- performance link. In this case, the de facto employing organization - the one that actually requires labor for production or service delivery - can negotiate participation-supporting terms into the contract with the employment agency or into the individual contract with an independent contractor. Ironically, this lever for controlling horizontal alignment would be less available to those workers and managers party to more traditional employment arrangements. As a result, the question of how nonstandard employment arrangements impinge upon the framework presented here and, more broadly, how they mediate the participation-performance link, remains an empirical one that calls for further examination.

Finally, the nose-to-tail framework hints at the potential research dividend to approaches that do not analyze the behavior of workers, departments, organizations, or industries per se, but rather consider the employment relationship as their unit-of-analysis. While some have argued for this reorientation on normative grounds (e.g., Kochan, 1999), one could instead make the case that these approaches offer more nuanced and more complete explanations for the behavior of workers, managers, and organizations. In fact, social scientists at least as far back as Commons (1909) presented the connections between actors as the appropriate unit-of- analysis, and social network theorists have constructed an entire literature and related set of methodological advances around the treatment of ties and systems of ties - not individual nodes - as apposite units-of-analysis (e.g., Burt, 1992; Granovetter, 1973). While fuller consideration of the theoretical and methodological implications of this shift in perspective requires its own study, suffice it to say that the nose-to-tail framework offered here - once validated empirically - could provide a promising new avenue for theory-building and application.

\section{NOTES}

1. Terms such as participation, involvement, empowerment, and voice, sometimes prepended with qualifiers such 
as worker, employee, direct or indirect, or online or offline, can be defined any number of ways and with varying degrees of specificity (Wilkinson \& Dundon, 2010). For the sake of uniformity and generality, this paper uses participation while acknowledging the mix and meaning of related terminology.

2. For a thorough and critical review of the participation literature to date, see the recent volume edited by Wilkinson, Gollan, Marchington, and Lewin (2010).

3. Despite what may be implied by their labels, the levels do not necessarily represent anything spatial or map into specific units-of-observation on the empirical plane. For example, one can examine differences in the terms and conditions of employment - functional-level constructs - by comparing organizations, comparing employment contracts, interviewing members of boards of directors, interviewing frontline workers, etc.

4. The three-tier framework, or more specifically, the "strategic choice" theory from which it is derived, was not without critics. Dunlop (1958 [1993]) essentially argued that there was no fundamental transformation in US industrial relations that would necessitate a revision to his seminal framework from Industrial Relations Systems, while Lewin (1987) offered a more nuanced critique of its conceptual and analytical shortcomings.

\section{ACKNOWLEDGMENTS}

The author is grateful to Ingrid Fulmer, Barry Gerhart, Jody Hoffer Gittell, Ellen Ernst Kossek, and Frits Pil for their comments and suggestions.

\section{REFERENCES}

Abdel-Halim, A. A. (1983). Effects of task and personality characteristics on subordinate responses to participative decision making. Academy of Management Journal, 26(3), 477-484.

Abdel-Halim, A. A., \& Rowland, K. M. (1976). Some personality determinants of the effects of participation: A further investigation. Personnel Psychology, 29(1), 41-55.

Appelbaum, E., Bailey, T., Berg, P., \& Kalleberg, A. L. (2000). Manufacturing advantage: Why high-performance work systems pay off. Ithaca, NY: Cornell/ILR.

Arthur, J. B. (1992). The link between business strategy and industrial relations systems in American steel minimills. Industrial and Labor Relations Review, 45(3), 488-506.

Arthur, J. B. (1994). Effects of human resource systems on manufacturing performance and turnover. Academy of Management Journal, 37(3), 670-687.

Bailey, T., Berg, P., \& Sandy, C. (2001). The effect of high-performance work practices on employee earnings in the steel, apparel, and medical electronics and imaging industries. Industrial and Labor Relations Review, 54(2A), 525-543.

Baird, L., \& Meshoulam, I. (1988). Managing two fits of strategic human resource management. Academy of Management Review, 13(1), 116-128.

Bandura, A. (1986). Social foundations of thought and action: A social cognitive theory. Englewood Cliffs, NJ: Prentice-Hall.

Batt, R., \& Banerjee, M. (2012). The scope and trajectory of strategic HR research: Evidence from American and British journals. International Journal of Human Resource Management, 23(9), 1739-1762.

Becker, B. E., \& Gerhart, B. (1996). The impact of human resource management on organizational performance: Progress and prospects. Academy of Management Journal, 30(4), 779-801.

Becker, B. E., \& Huselid, M. A. (1998). High performance work systems and firm performance: A synthesis of research and 
managerial implications. In G. Ferris (Ed.), Research in personnel and human resources management (Vol. 16, pp. 53-101). Greenwich, CT: JAI Press.

Becker, B. E., \& Huselid, M. A. (2010). Strategic human resources management: Where do we go from here? In A. Wilkinson, N. Bacon, T. Redman, \& S. Snell (Eds.), The Sage handbook of human resource management (pp. 351376). London: Sage.

Bidwell, M., \& Fernandez-Mateo, I. (2008). Three's a crowd? Understanding triadic employment relationships. In P. Cappelli (Ed.), Employment relationships: New models of white-collar work (pp. 142-178). Cambridge, MA: Cambridge University.

Blasi, J. R., \& Kruse, D. L. (2006). US high-performance work practices at century's end. Industrial Relations, 45(4), 547578.

Bonet, R., Cappelli, P., \& Hamori, M. (2013). Labor market intermediaries and the new paradigm for human resources. Academy of Management Annals, 7(1), 339-390.

Brown, M., \& Cregan, C. (2008). Organizational change cynicism: The role of employee involvement. Human Resource Management, 47(4), 667-686.

Bryson, A., Forth, J., \& Kirby, S. (2005). High-involvement management practices, trade union representation and workplace performance in Britain. Scottish Journal of Political Economy, 52(3), 451-491.

Budd, J. W. (2004). Employment with a human face: Balancing efficiency, equity, and voice. Ithaca, NY: Cornell/ILR.

Burt, R. S. (1992). Structural holes: The social structure of competition. Cambridge, MA: Harvard University Press.

Cappelli, P., \& Neumark, D. (2001). Do "high-performance” work practices improve establishment-level outcomes? Industrial and Labor Relations Review, 54(4), 737-775.

Carroll, G. (1987). Publish and perish: The organizational ecology of newspaper industries. Greenwich, CT: JAI Press.

Coch, L., \& French, J. R. P., Jr. (1948). Overcoming resistance to change. Human Relations, 1(4), 512-532.

Commons, J. R. (1909). American shoemakers, 1648-1895: A sketch of industrial evolution. Quarterly Journal of Economics, 24(1), 39-98.

Connor, P. E. (1992). Decision-making participation patterns: The role of organizational context. Academy of Management Journal, 35(1), 218-231.

Cox, A., Zagelmeyer, S., \& Marchington, M. (2006). Embedding employee involvement and participation at work. Human Resource Management Journal, 16(3), 250-267.

Dean, J. W., Jr., \& Snell, S. A. (1991). Integrated manufacturing and job design: Moderating effects of organizational inertia. Academy of Management Journal, 34(4), 776-804.

Delery, J. E., \& Doty, D. H. (1996). Modes of theorizing in strategic human resource management: Tests of universalistic, contingency, and configurational performance predictions. Academy of Management Journal, 39(4), 802-835.

Dunlop, J. T. (1958 [1993]). Commentary: Industrial relations systems (Rev. ed., pp. 1-41). Boston, MA: Harvard Business School.

Eaton, A. E., Konitsney, D., Litwin, A. S., \& Vanderhorst, N. (2011). The path to performance: A study of high-performing unit-based teams at Kaiser Permanente. Oakland, CA: Kaiser Permanente.

Frenkel, S., Korczynski, M., Shire, K., \& Tam, M. (1999). On the front line: Organization of work in the information economy. Ithaca, NY: Cornell/ILR.

Gerhart, B. (2007). Horizontal and vertical fit in human resource systems. In C. Ostroff, \& T. A. Judge (Eds.), Perspectives on organizational fit (pp. 317-348). New York, NY: Lawrence Erlbaum.

Glew, D. J., O'Leary-Kelly, A. M., Griffin, R. W., \& Van Fleet, D. D. (1995). Participation in organizations: A preview of the issues and proposed framework for future analyses. Journal of Management, 21(3), 395-421.

Granovetter, M. S. (1973). The strength of weak ties. American Journal of Sociology, 78(6), 1360-1380. 
Griffin, R. W. (1988). Consequences of quality circles in an industrial setting: A longitudinal assessment. Academy of Management Journal, 31(2), 338-358.

Hannan, M. T., \& Freeman, J. (1977). The population ecology of organizations. American Journal of Sociology, 82(5), 929964.

Hannan, M. T., \& Freeman, J. (1984). Structural inertia and organizational change. American Sociological Review, 49, 149164.

Henderson, F. (2004). The whole beast: Nose to tail eating. New York, NY: Harper Collins.

Hitt, L. M., \& Brynjolfsson, E. (1997). Information technology and internal firm organization: An exploratory analysis. Journal of Management Information Systems, 14(2), 81 - 101.

Huselid, M. A. (1995). The impact of human resource practices on turnover, productivity, and corporate financial performance. Academy of Management Journal, 38(3), 635-872.

Ichniowski, C., \& Shaw, K. (2013). Insider econometrics: Empirical studies of how management matters. In R. Gibbons \& J. Roberts (Eds.), The handbook of organizational economics (pp. 263-311). Princeton, NJ: Princeton University.

Ichniowski, C., Shaw, K., \& Prennushi, G. (1997). The effects of human resource management practices on productivity: A study of steel finishing lines. American Economic Review, 87(3), 291-313.

Jensen, M. C., \& Meckling, W. H. (1976). Theory of the firm: Managerial behavior, agency costs and ownership structure. Journal of Financial Economics, 3(4), 305-360.

Jones, D. C., Kalmi, P., \& Kauhanen, A. (2010a). How does employee involvement stack up? The effects of human resource management policies in a retail firm. Industrial Relations, 49(1), 1-21.

Jones, D. C., Kalmi, P., \& Kauhanen, A. (2010b). Teams, incentive pay, and productive efficiency: Evidence from a foodprocessing plant. Industrial and Labor Relations Review, 63(4), 606-626.

Kalleberg, A. L., Rasell, E., Cassirer, N., Reskin, B. F., Hudson, K., \& Webster, D. (1997). Nonstandard work, substandard jobs: Flexible work arrangements in the US. Washington, DC: Economic Policy Institute.

Kalleberg, A. L., Reskin, B. F., \& Hudson, K. (2000). Bad jobs in America: Standard and nonstandard employment relations and job quality in the US. American Sociological Review, 65, 256-278.

Kanter, R. M. (1983). The change masters: Innovation and entrepreneurship in the American corporation. New York, NY: Simon \& Schuster.

Kato, T., \& Morishima, M. (2002). The productivity effects of participatory employment practices: Evidence from new Japanese panel data. Industrial Relations, 41(4), 487-520.

Katz, H. C., Kochan, T. A., \& Colvin, A. J. S. (2008). An introduction to collective bargaining and industrial relations (4th ed.). Boston, MA: McGraw-Hill/Irwin.

Kaufman, B. E. (2014). The historical development of American HRM broadly viewed. Human Resource Management Review, 24(3), 196-218.

Kerr, S. (1975). On the folly of rewarding A while hoping for B. Academy of Management Journal, 18(4), 769-783.

Khilji, S. E., \& Wang, X. (2006). "Intended" and "implemented” HRM: The missing linchpin in strategic human resource management research. International Journal of Human Resource Management, 17(7), $1171-1189$.

Klein, J. A. (2003). Changing relations between supervisors and employees: From deal making to strategic negotiations. In T. A. Kochan \& D. B. Lipsky (Eds.), Negotiations and change: From the workplace to society (pp. 54-69). Ithaca, NY: Cornell/ILR.

Kochan, T. A. (1999). Beyond myopia: Human resources and the changing social contract. In P. M. Wright, L. D. Dyer, J. W. Boudreau, G. T. Milkovich, \& G. Ferris (Eds.), Research in personnel and human resources management (Vol. 4, pp. 199-212). Stamford, CT: JAI Press.

Kochan, T. A., Eaton, A. E., McKersie, R. B., \& Adler, P. S. (2009). Healing together: The labor-management partnership at Kaiser Permanente. Ithaca, NY: Cornell/ILR. 
Kochan, T. A., Katz, H. C., \& McKersie, R. B. (1986). The transformation of American industrial relations. New York, NY: Basic Books.

Kochan, T. A., McKersie, R. B., \& Cappelli, P. (1984). Strategic choice and industrial relations theory. Industrial Relations, 23(1), 16-39.

Kren, L. (1992). The moderating effects of locus of control on performance incentives and participation. Human Relations, 45(9), $991-1012$.

Latham, G. P., Winters, D. C., \& Locke, E. A. (1994). Cognitive and motivational effects of participation: A mediator study. Journal of Organizational Behavior, 15(1), 49-63.

Laursen, K., \& Foss, N. J. (2003). New human resource management practices, complementarities and the impact on innovation performance. Cambridge Journal of Economics, 27(2), 243-263.

Lavelle, J., Gunnigle, P., \& McDonnell, A. (2010). Patterning employee voice in multinational companies. Human Relations, 63(3), 395-418.

Lawler, E. E., III, \& Mohrman, S. A. (1987). Quality circles: After the honeymoon. Organizational Dynamics, 15(4), $42-54$.

Leana, C. R., \& Florkowski, G. W. (1992). Employee involvement programs: Integrating psychological theory and management practice. Research in Personnel and Human Resources Management, 10, 233-270.

Lengnick-Hall, C. A., \& Lengnick-Hall, M. L. (1988). Strategic human resources management: A review of the literature and a proposed typology. Academy of Management Review, 13(3), 454-470.

Lepak, D. P., \& Snell, S. A. (2002). Examining the human resource architecture: The relationship among human capital, employment, and human resource configurations. Journal of Management, 28(4), 517-543.

Levine, D. I., \& Tyson, L. D. A. (1990). Participation, productivity, and the firm's environment. In A. S. Blinder (Ed.), Paying for productivity: A look at the evidence (pp. 183-243). Washington, DC: Brookings.

Lewin, D. (1987). Industrial relations as a strategic variable. In M. M. Kleiner, R. N. Block, M. Roomkin, \& S. W. Salsburg (Eds.), Human resources and the performance of the firm (pp. 1-41). Madison, WI: Industrial Relations Research Association.

Litwin, A. S. (2011). Technological change at work: The impact of employee involvement on the effectiveness of health information technology. Industrial and Labor Relations Review, 64(5), 863-888.

Litwin, A. S. (2013). Not featherbedding, but feathering the nest: Human resource management and investments in information technology. Industrial Relations, 52(1), 22-52.

Litwin, A. S., \& Eaton, A. E. (2014). Participative management or managed participation? Worker participation and the mystery of the missing performance effects. SSRN Working Paper No. 2201704. Social Science Research Network, Rochester, NY.

Locke, E. A., \& Schweiger, D. M. (1979). Participation in decision-making: One more look. Research in Organizational Behavior, 1, 265-339.

MacDuffie, J. P. (1995). Human-resource bundles and manufacturing performance: Organizational logic and flexible production systems in the world auto industry. Industrial and Labor Relations Review, 48(2), 197-221.

Makadok, R., \& Coff, R. (2009). Both market and hierarchy: An incentive-system theory of hybrid governance. Academy of Management Review, 34(2), 297-319.

March, J. G., \& Simon, H. A. (1958). Organizations. New York, NY: Wiley.

Marchington, M., Grimshaw, D., Rubery, J., \& Willmott, H. (Eds.). (2005). Fragmenting work: Blurring organizational boundaries and disordering hierarchies. New York, NY: Oxford.

Marchington, M., \& Suter, J. (2013). Where informality really matters: Patterns of employee involvement and participation (EIP) in a non-union firm. Industrial Relations, 52(S1), 284-313.

Marchington, M., \& Wilkinson, A. (2000). Direct participation. In S. Bach \& K. Sisson (Eds.), Personnel management: A comprehensive guide to theory and practice (3rd ed., pp. 340-364). Oxford: Blackwell. 
Marchington, M., \& Wilkinson, A. (2005). Direct participation and involvement. In S. Bach (Ed.), Managing human resources: Personnel management in transition (pp. 398-423). Oxford: Blackwell.

Marsden, D., \& Canibaüo, A. (2010). An economic perspective on employee participation. In A. Wilkinson, P. J. Gollan, M. Marchington, \& D. Lewin (Eds.), Oxford handbook of participation in organizations (pp. $131-163$ ). New York, NY: Oxford.

McCurdy, H. C., \& Eber, H. W. (1953). Democratic versus authoritarian: A further investigation of group problem-solving. Journal of Personality, 22(2), 258-269.

McGregor, D. M. (1960). The human side ofenterprise. New York, NY: McGraw-Hill.

Meyer, J. W., \& Rowan, B. (1977). Institutionalized organizations: Formal structure as myth and ceremony. American Journal of Sociology, 83(2), 340-363.

Milgrom, P., \& Roberts, J. (1992). Economics, organization and management. Upper Saddle River, NJ: Prentice-Hall.

Miller, K. I., \& Monge, P. R. (1986). Participation, satisfaction, and productivity: A metaanalytic review. Academy of Management Journal, 29(4), 727-753.

Neumann, J. E. (1987). Why people don't participate in organizational change. In R. Woodman, \& W. Pasmore (Eds.), Research in organizational change and development (Vol. 3, pp. 181-212). Greenwich, CT: JAI Press.

Osterman, P., \& Burton, M. D. (2005). Ports and ladders: The nature and relevance of internal labor markets in a changing world. In S. Ackroyd, R. Batt, P. Thompson, \& P. Tolbert (Eds.), Oxford handbook of work and organization (pp. 425445). New York, NY: Oxford University Press.

Ouchi, W. G. (1981). Theory Z: How American business can meet the Japanese challenge. Reading, MA: Addison-Wesley.

Peters, P., Poutsma, E., Van der Heijden, B. I. J. M., Bakker, A. B., \& de Bruijn, T. (2014). Enjoying new ways to work: An HRM-process approach to study flow. Human Resource Management, 53(2), 271-290.

Pfeffer, J. (1994). Competitive advantage through people: Unleashing the power of the work force. Boston, MA: Harvard Business School.

Pfeffer, J., \& Baron, J. N. (1988). Taking the workers back out: Recent trends in the structuring of employment. Research in Organizational Behavior, 10, 257-303.

Poutsma, E., Ligthart, P. E. M., \& Veersma, U. (2006). The diffusion of calculative and collaborative HRM practices in European firms. Industrial Relations, 45(4), 513-546.

Riordan, C. M., Vandenberg, R. J., \& Richardson, H. A. (2005). Employee involvement climate and organizational effectiveness. Human Resource Management, 44(4), 471-488.

Robinson, S. L., Kraatz, M. S., \& Rousseau, D. M. (1994). Changing obligations and the psychological contract: A longitudinal study. Academy of Management Journal, 37(1), 137-152.

Rubinstein, S. A. (2003). Partnerships of steel? Forging high involvement work systems in the US steel industry: A view from the local unions. Advances in Industrial and Labor Relations, 12, 117-146.

Sagie, A., \& Koslowsky, M. (1994). Organizational attitudes and behaviors as a function of participation in strategic and tactical change decisions: An application of path-goal theory. Journal of Organizational Behavior, 15(1), 37-47.

Simon, H. A. (1951). A formal theory of the employment relationship. Econometrica, 19(3), $293-305$.

Singh, J. V., House, R. J., \& Tucker, D. J. (1986). Organizational change and organizational mortality. Administrative Science Quarterly, 31(4), 587-611.

Snell, S. A., \& Dean, J. W., Jr. (1994). Strategic compensation for integrated manufacturing: The moderating effects of jobs and organizational inertia. Academy of Management Journal, 37(5), 1109-1140.

Steers, R. M. (1977). Individual differences in participative decision-making. Human Relations, 30(9), 837-847.

Useem, M. (1992). Corporate restructuring and organizational behavior. In T. A. Kochan \& M. Useem (Eds.), Transforming organizations (pp. 44-59). New York, NY: Oxford. 
Vroom, V. H. (1959). Some personality determinants of the effects of participation. Journal of Abnormal and Social Psychology, 59(3), 322-327.

Vroom, V. H. (1960). Some personality determinants of the effects of participation. Englewood Cliffs, NJ: Prentice-Hall.

Vroom, V. H., \& Deci, E. L. (1960). Management and motivation. Baltimore, MD: Penguin.

Vroom, V. H., \& Yetton, P. W. (1973). Leadership and decision-making. Pittsburgh, PA: University of Pittsburgh.

Wageman, R. (1995). Interdependence and group effectiveness. Administrative Science Quarterly, 40(1), 145-180.

Wagner, J. A., III (1994). Participation's effects on performance and satisfaction: A reconsideration of research evidence. Academy of Management Review, 19(2), 312-330.

Wagner, J. A., III, \& Gooding, R. Z. (1987). Shared influence and organizational behavior: A meta-analysis of situational variables expected to moderate participation-outcome relationships. Academy of Management Journal, 30(3), $524-541$.

Wagner, J. A., III, Leana, C. R., Locke, E. A., \& Schweiger, D. M. (1997). Cognitive and motivational frameworks in US research on participation: A meta-analysis of primary effects. Journal of Organizational Behavior, 18(1), 49-65.

Wall, T. D., \& Wood, S. J. (2005). The romance of human resource management and business performance and the case for big science. Human Relations, 58(4), 429-462.

Wilkinson, A., \& Dundon, T. (2010). Direct employee participation. In A. Wilkinson, P. J. Gollan, M. Marchington, \& D. Lewin (Eds.), Oxford handbook of participation in organizations (pp. 167-185). New York, NY: Oxford.

Wilkinson, A., \& Fay, C. (2011). New times for employee voice? Human Resource Management, 50(1), 65-74.

Wilkinson, A., Gollan, P. J., Marchington, M., \& Lewin, D. (Eds.). (2010). Oxford handbook of participation in organizations. New York, NY: Oxford.

Wright, P. M., \& McMahan, G. C. (1992). Theoretical perspectives for strategic human resource management. Journal of Management, 18(2), 295-320.

Wright, P. M., \& Snell, S. A. (1998). Toward a unifying framework for exploring fit and flexibility in strategic human resource management. Academy of Management Review, 23(4), 756-772.

Youndt, M. A., Snell, S. A., Dean, J. W., Jr., \& Lepak, D. P. (1996). Human resource management, manufacturing strategy, and firm performance. Academy of Management Journal, 39(4), 836-866. 